in a hundred million during an interval of only one minute, but such tests as have already been made indicate that the fluctuations due to the action of the thermal regulation are less than one part in a hundred million.

"Sufficient experience has now been accumulated," the report says, "to enable the statement to be made that properly designed and steadily operated tuning-forks form a primary frequency standard of reliability of about one part in ten million, a result fully equal to that of the best pendulum clocks. It is an interesting fact that the slight earthquake experienced in the south-east of England on June 7, 1931, caused a small change in rate of the pendulum clock of about four parts in ten million, which was revealed on the tuningfork chronograph, the tuning-fork being unaffected by the shock."
It has now become necessary to develop apparatus to resolve the differences between the tuningfork and the clock to enable short period fluctuations to be accurately observed. For this purpose radial vibrations of a small quartz crystal very carefully cut in the form of a ring are used to control the oscillation of a valve generator. The experiments carried out give good hope that a standard which is permanent and accurate to one part in a hundred million may be obtained in the near future.

The above review is by no means exhaustive of the contents of the report, which shows that the organisation controlled by the Radio Research Board continues the active pursuit of radio research and development, which in the past few years has placed Great Britain in a world-renowned position.

\title{
Obituary
}

\section{Prof. James Johnstone}

IAMES JOHNSTONE, the distinguished zoologist, oceanographer and philosopher, died at the age of sixty-two years at his home in Lochwinnoch on December 27 after a sudden attack of influenza. He appeared to have recovered from his former dangerous illness, so that his loss from an apparently accidental infection is felt the more keenly. He was not married.

There can be no doubt that he was a man of exceptional ability with an unusually wide knowledge of science; and a fearless and original thinker. Though reticent and even shy, "J. J.", as he was familiarly called, endeared himself to all those who had much to do with him by his kindly and sympathetic manner and his philosophical outlook on life's problems. It is characteristic of him that he was especially concerned about the future prospects of the junior staff and servants employed in his Department.

The future philosopher showed his naturalistic leanings as a boy when he roamed the country observing wild animals and collecting birds' eggs; he exhibited the urge of the 'vital impetus' which was to concern him greatly later-when as a young man he 'emerged' from the environment of a journeyman wood-carver by attending evening classes at Lochwinnoch and at Glasgow. By the encouragement of his teacher and coach, Robert Logan, and the facilities afforded by the local school board and the Board of Education, he was enabled at the late age of twenty-five to begin the study of the biological sciences at the Royal College of Science, London, mainly under Prof. G. B. Howes. Before graduating in 1900 at the University of London he had already written one paper on the thymus in marsupials and two on fisheries subjects.

On his appointment in 1898 as fisheries assistant to Sir William (then Prof.) Herdman on the research staff of the Lancashire and Western Sea
Fisheries Committee, Johnstone found a congenial environment; he threw himself with remarkable energy into studies in fisheries and the more general aspects of marine biology with such success that he had become a leading figure in British marine biology in 1908. This early success can be traced to his great interest in fisheries, to his unusually logical mind, and a great capacity for absorbing masses of data while perceiving and retaining a clear recollection of their interrelations, which he was able to expound in simple language. These faculties enabled him to bring together material on the growth and origin of "British Fisheries" (1905). The amassing of this material and his practical fishery experience placed him at once in a commanding position to give valuable support to the work of the newly instituted International Council for Fishery Investigations. The same faculties enabled him to produce an illuminating and classical work (1908) on "Conditions of Life in the Sea". This book was undoubtedly for many years a source of information and inspiration to the rising generation of marine biologists; in it he propounded a surprising proportion of the major problems which have been successfully investigated in recent years.

The basis of Johnstone's knowledge of fisheries lay in his experience in inshore and offshore work and the study of plankton in collaboration with his life-long friend, Andrew Scott. He also helped to lay the foundation for later successful work on the purification of shellfish. Marine bacteria were of great interest to him; his work led him to speculate on the existence in the sea of pathogenic types comparable with those found in terrestrial animals. He described a large number of malignant 'cancerous' tumours in fish, two of these being defined as of a "piscine tuberculosis" type, and accompanied these studies with extended investigations on parasites. His knowledge of this branch of pathology was associated with a vivid interest in human 'cancer', and its treatment by 
radium. Probably a real satisfaction in his lifebetrayed in unguarded moments - was the success attending his share in the effort to procure radium for the Liverpool Radium Institute and Hospital for Cancer and Skin Diseases.

During the War, Johnstone's work on the dietetic value of fishes gained him an effective position on the Fish Preservation Committee of the Food Investigation Board of the Department of Scientific and Industrial Research.

In 1919, Johnstone was appointed lecturer in oceanography at the University of Liverpool and a year later he succeeded Sir William Herdman to the chair. In this new capacity he was fortunately able to indulge his leaning towards scholarship and philosophy. His works on oceanography brought up to date our knowledge of the physical features of the oceans ; at the same time the story of the origin of the oceans is treated in a manner of fascinating interest to the students of geography and geology ; "A Study of the Oceans" is indeed a new approach to the study of geography in a wide sense. Along with this work he undertook as director the reorganisation of the Port Erin Marine Biological Station and effected great improvements.

In later life the totality of the relations between things became to our savant-as to many other older scientific workers - of greater interest than lesser relations. He had already in 1914 surveyed the "Philosophy of Biology" and had stated the problems in his usual clear manner. These he elaborated later in "Mechanism of Life", and made what proved to be a final contribution recently in "Essentials of Biology" (1932). Here the fundamental problems of biology are discussed simply and logically with a rare clarity and impartiality. On the problem of the origin of life he refines his views of 1914 to the simple statement that ". . . it may be the case that the problem is only a pseudo one and that it is just as foolish to inquire into the origin of life as it would be to ask what was the origin of the universal tendency to entropy increase. We have no doubt that the distinction between living and lifeless things is a problem for physics [present writer's italics]. We have no confidence that the basal conceptions of physics have been established. That being so, it is futile further to continue this discussion".

On this problem-as on many others-the philosopher and research worker discloses the apparent inadequacies of present-day knowledge. In this way James Johnstone leaves his problems and work to posterity, with a satisfying and rare record of achievement; and better still, he leaves a memory of a loveable man, wise and humble, great and unassuming.

\section{Prof. C. M. Thompson}

Claude Metrord Thompson, emeritus professor of chemistry of the University College, Cardiff, was born at Bridgwater in 1855, and was the son of Alexander and Eleanor Thompson. He died at Cardiff on January 4, 1933, at the age of seventy-seven years. Some of the following particulars of his career are from the Western Mail. Prof. Thompson was educated at University College, London; Trinity College, Cambridge, where he was a scholar; and the University of Bonn. At Cambridge he obtained the degree of M.A. ; his D.Sc. was awarded to him by the University of London, which university also bestowed upon him a gold medal for distinction in his subject; and the University of Wales conferred upon him the degree of D.Sc. (honoris causa) for his services during and after its institution in 1893. He was the last of the original professors appointed in 1883 when the University College, Cardiff, was opened under the principalship of Viriamu Jones, and he retired from the service of the College in 1921, with the title of emeritus professor, after a successful career as professor of chemistry.

Dr. Thompson's assistance and advice to the University and the University College were particularly useful regarding the details of educational organisation and in the preparation of regulations, courses, and schemes of study for degrees. Up to the time of his death he was a member of the Court of Governors of the College, appointed by the Chancellor of the University of Cambridge. He found time to carry on research work, particularly into the constituents and possible uses of rare earths and their application to commercial products, such as incandescent mantles.

Dr. Thompson was a generous supporter of the University College at Cardiff, and the donor of many volumes and publications on chemistry to its library. In his early days he found his chief enjoyment in mountaineering during vacations; he was a member of the Alpine Club. He identified himself with local interests by becoming a member of the Cardiff Naturalists' Society, in the work of which he was particularly active. He took a keen delight in gardening, and many of the amenities to be found in "Cae Syr Dafydd", one of Cardiff's parks, are largely due to his care and attention.

A. A. R.

WE regret to announce the following deaths:

Mr. T. H. Coward, a well-known naturalist and an authority on British birds, on January 29, aged sixty-six years.

Sir Percy Sargent, C.M.G., formerly surgeon to St. Thomas's Hospital and the National Hospital, Queen Square, London, and Hunterian professor of surgery and pathology at the Royal College of Surgeons in 1928, an authority on brain surgery, on January 22, aged fifty-nine years.

Dr. John Thomas, joint managing director of the Dyestuffs Group of Imperial Chemical Industries, Ltd., a well-known authority on dye-stuffs, on January 18, aged forty-six years. 